\title{
Therapeutic Treatment of New Zealand Mouse Disease by a Limited Number of Anti-idiotypic Antibodies Conjugated with Neocarzinostatin
}

Naoko Harata, Takeshi Sasaki, Hirofumi Osaki, Takao Saito, Shinobu Shibata, Tai Muryoi, Osamu Takai, and Kaoru Yoshinaga Second Department of Internal Medicine, Tohoku University School of Medicine, Sendai, 980 Japan

\begin{abstract}
0-81 and NE-1 idiotypes (Id) of human nephritogenic antiDNA antibodies are interspecies Id expressed also in NZB/W $F_{1}$ mice. We tried to manipulate the synthesis of spontaneously occurring anti-DNA antibody using monoclonal anti-Id antibodies (D1E2 and 1F5) conjugated with a cytotoxic agent, neocarzinostatin (NCS). In vivo administration of anti-Id antibodies conjugated with NCS brought about an improvement in the survival rate of female $N Z B / W F_{1}$ mice. It also caused a retardation of development of lupus nephritis and decreased the numbers of anti-DNA-producing cells. The suppression of anti-DNA antibody synthesis was specific and Id-mediated. The results indicate that the use of a limited number of anti-Id antibodies in combination with a cytotoxic agent may be applicable therapeutically to autoimmune diseases. (J. Clin. Invest. 1990. 86:769-776.) Key words: anti-DNA antibodies - antiidiotype • neocarzinostatin • systemic lupus erythematosus
\end{abstract}

\section{Introduction}

Autoantibodies are closely associated with the pathogenesis of autoimmune diseases. For example, antibodies to the acetylcholine receptor cause myasthenia gravis (1), and Coomb's antibodies are responsible for autoimmune hemolytic anemia (2). This led us to speculate that specific manipulation of autoantibody production might lead to a new therapy for autoimmune diseases (3-5).

Anti-idiotypic antibodies have the ability to regulate the production of relevant idiotype (Id)-positive antibodies in vivo as well as in vitro (6-8). The antibodies may also make it possible to control pathogenetic antibody synthesis in autoimmune states. Along this line, several studies have demonstrated the suppressive ability of anti-Id antibodies on the synthesis of autoantibodies in vitro $(3,4,9-12)$. Anti-Id immunity, however, is not a simple matter in the case of immune responses in vivo: for example, the administration of low doses of anti-Id antibodies has been shown to cause an enhanced response to dinitrophenyl (DNP) $(13,14)$. Furthermore, anti-Id antibodies with internal image ( $\mathrm{Ab} 2 \beta$ activity) have also elicited the production of antithyroglobulins when administered in $\mathrm{C} 3 \mathrm{H} /$ He mice (15). In vivo administration of anti-Id antibodies in $\mathrm{NZB} / \mathrm{W} \mathrm{F}_{1}$ mice has induced the transient suppression of

Address reprint requests to Dr. Sasaki, Second Department of Internal Medicine, Tohoku University School of Medicine, Seiryocho 1-1, Sendai 960, Japan.

Received for publication 30 October 1989 and in revised form 9 May 1990.

\section{J. Clin. Invest.}

(c) The American Society for Clinical Investigation, Inc. 0021-9738/90/09/0769/08 $\$ 2.00$

Volume 86, September 1990, 769-776
anti-DNA synthesis, which is, however, replaced by Id-negative anti-DNA production (16). A similar trial had no effect on MRL/lpr mice (17). This may be attributed to the complexity of anti-Id immunity in vivo; anti-Id antibodies might work not only on clones with regulatory ability, but also on those with an enhancing capacity in the immune network system, resulting in dual effects on immune responses in vivo (16, 18). Another problem is in the choice of anti-Id antibodies, which should have the ability to target specific pathogenetic anti-DNA antibodies among numerous antibodies. Thus, therapeutic application of anti-Id immunity to autoimmune disease has been hampered because of the problems above mentioned.

We developed a new way to manipulate anti-DNA synthesis using anti-Id antibodies in combination with a cytotoxic agent, neocarzinostatin (NCS) ${ }^{1}$ (19). Anti-Id antibodies designated as D1E2 or 1F5 were directed to anti-DNA antibodies that were nephritogenic in patients with systemic lupus erythematosus (SLE) (20). This procedure was capable of manipulating anti-DNA responses through the specific elimination of Id-positive cells in a human in vitro system (21). It was, however, unknown as to what would be evoked by this procedure in vivo. In this paper, we present a successful treatment of NZB/W $F_{1}$ mice disease by using anti-Id-conjugated NCS.

\section{Methods}

Animals. NZB and NZW mice were purchased from the Shizuoka Laboratory Animal Center (Shizuoka, Japan), and maintained by brother-sister mating at the Institute for Experimental Animals, Tohoku University.

Reagents. Calf thymus DNA was obtained from Worthington Biochemicals, Freehold, NJ. The DNA was further purified into doublestranded (ds) and single-stranded (ss) DNA (22). Human monoclonal anti-DNA antibodies (0-81 and NE-1) were obtained from B cell clones established by Epstein-Barr virus (EBV) transformation methods (23). 0-81 antibody binds preferentially to ss-homopolymer with pyrimidine bases; NE-1 reacts not only with ssDNA but also with dsDNA, RNA, and cardiolipin (24). Two types of monoclonal anti-Id antibody (D1E2 and 1F5) to human monoclonal anti-DNA antibody (0-81 and NE-1) were obtained from mouse hybridoma using cells immunized with 0-81 or NE-1 (25). D1E2 (IgG 1) binds to Id including the antigen-binding site of 0-81 and inhibits the binding of $0-81$ to ssDNA but not reacts with NE-1. 1F5 (IgG 1) specifically reacts with NE-1 but never with 0-81 (26). $\mathrm{F}\left(\mathrm{ab}^{\prime}\right)_{2}$ fragments of anti-Id antibodies (D1E2 and 1F5) were produced by the standard method.

Preparation of anti-Id-conjugated NCS. Purified NCS $(5 \mathrm{mg} / \mathrm{ml}$, Kayaku Antibiotics Research Co. Ltd., Tokyo) or anti-Id antibodies (D1E2, 1F5) were first incubated with a fourfold molar excess of $\mathrm{N}$ succinimidyl 3-(2-pyridyldithio) propionate (Pharmacia Fine Chemicals, Uppsala, Sweden) in a $0.1 \mathrm{M}$ phosphate buffer, $\mathrm{pH} 6.5$, at $25^{\circ} \mathrm{C}$

1. Abbreviations used in this paper: IEF, isoelectric forusing; NCS, neocarzinostatin; PFC, plaque-forming cell; SLE, systemic lupus erythematosus; ssDNA and dsDNA, single- and double-stranded DNA. 
for $30 \mathrm{~min}$. The 3-(2-pyridyldithio)-propionylated NCS was reduced with $10 \mathrm{mM}$ dithiothreitol (Wako Pure Chemicals Industries, Tokyo) in a $0.1 \mathrm{M}$ acetate buffer, $\mathrm{pH} 4.5$, at $25^{\circ} \mathrm{C}$ for $30 \mathrm{~min}$. The resulting NCS that contained the thiol groups was immediately passed through a Sephadex G-25 column. Anti-Id antibody to anti-DNA antibody (2.8 $\mathrm{mg} / \mathrm{ml}$ ) or control mouse IgG was incubated with a 10-fold molar excess of $\mathrm{N}$-succinimidyl 3-(2-pyridyldithio) propionate in a $0.1 \mathrm{M}$ phosphate buffer, $\mathrm{pH} 6.5$, at $25^{\circ} \mathrm{C}$ for $30 \mathrm{~min}$, and 3-(2-pyridyldithio) propionate antibody was purified by gel filtration on a Sephadex G-25 column. Finally, 3-(2-pyridyldiothio) propionylate antibody was mixed with a sixfold molar excess of $N$-succinimidyl 3-(2-pyridyldithio)-propionate-linked NCS, and allowed to stand at $25^{\circ} \mathrm{C}$ overnight in the dark. The mixture was then applied to a Sephacryl S-200 column equilibrated with PBS ( $\mathrm{pH}$ 6.0) and eluted with the same buffer. The second peak fractions were pooled, concentrated, and used as anti-Id-NCS. NCS activity of the conjugated preparation was measured by an agar dilution method by using Micrococcus luteus (ATCC 9341, American Type Culture Collection, Rockville, MD) as the sensitive microorganism and expressed as units per milliliter (27). The extent of substitution in this preparation was $\sim 1 \mathrm{~mol}$ of NCS per mol of IgG (28).

Experimental protocols. In preliminary studies, dose-response relationships were checked for Id-NCS and peritoneal injections of $10 \mathrm{U}$ of NCS/ $/ \mathrm{kg}$ were confirmed to be nontoxic to NZB/W $F_{1}$ mice because of undisturbed increase in weight or immune responses to dinitrophenyl-key hole limpet (DNP-KLH). At the first series of the experiments, female NZB/W $F_{1}$ mice were divided into three groups of 18-20 mice and given D1E2-NCS or NCS conjugated with IgG from BALB/c mice (mouse Ig-NCS) intraperitoneally at $10 \mathrm{U} / \mathrm{kg}$ of NCS beginning at $4 \mathrm{mo}$ of age. In the other series, female NZB/W $F_{1}$ mice at 4 mo of age were also divided into three groups of 20-25 mice and administered the mixture solution including D1E2-NCS plus 1F5NCS (10 U/kg of NCS), or that of mouse Ig-NCS. This treatment was repeated at 2-wk intervals for $7 \mathrm{mo}$. All mice were killed at $11 \mathrm{mo}$ of age to study antibody synthesis.

Urinalysis and light microscopy in kidney section. Freshly voided urine samples were tested by a method described by Knight et al. (29). The degree of proteinuria was evaluated based on the following scoring: 0 , urinary protein $<37 \mathrm{mg} / \mathrm{dl} ; 1, \geqq 37 \mathrm{mg} / \mathrm{dl} ; 2$, $\geqq 111 \mathrm{mg} / \mathrm{dl} ; 3$, $\geqq 333 \mathrm{mg} / \mathrm{dl}$.

The kidney sections $(2.5 \mu \mathrm{m}$ thick) from each mice at $11 \mathrm{mo}$ of age were stained with hematoxylin and eosin (H \& E), periodic acid-Schiff (PAS), and Azan-Mallory. The glomerular injury in each case was evaluated using activity index and chronicity index introduced by Austin et al. (30). Namely, the activity index was defined as the sum of individual scores of the following items: glomerular proliferation, leukocyte exudation, karyorrhexis/fibrinoid necrosis $(\times 2)$, cellular crescent $(\times 2)$, hyaline deposits, and interstitial inflammation. The chronicity index was expressed as the sum of the scores for the following items: glomerular sclerosis, fibrous crescents, tubular atrophy, and interstitial fibrosis.

Elution of immunoglobulins from kidneys. The renal tissues from six mice of each group were chopped into small pieces, respectively suspended in 0.15 M PBS, pH 7.2, and then homogenized in a chilled blender (Waring Products Div., New Hartford, CT). Then the renal glomeruli were obtained by a sieving method. The glomeruli obtained were washed repeatedly with PBS by centrifugation at $2,000 \mathrm{~g}$, until the optical density of the supernatant fell below OD 0.05 at $280 \mathrm{~nm}$. The pellets were then suspended in $0.1 \mathrm{M}$ citrate buffer, $\mathrm{pH} 3.2$, and incubated at $37^{\circ} \mathrm{C}$ for $1 \mathrm{~h}$ with continuous shaking. After centrifugation at $2,000 \mathrm{~g} 4^{\circ} \mathrm{C}$ for $15 \mathrm{~min}$, the supernatants were pooled and dialyzed against water for $2 \mathrm{~h}$, then against $0.02 \mathrm{M}$ PBS, pH 7.2, for $24 \mathrm{~h}$. The eluates were concentrated $\sim 25$-fold with a filter (Amicon Corp., Danvers, MA) and stored at $-70^{\circ} \mathrm{C}$ until use.

In vitro culture. Spleen cell suspensions were prepared by teasing the tissue in cold RPMI 1640 and allowing larger particles to settle. The suspended cells were washed three times and the cells $\left(1 \times 10^{6}\right.$ per well $)$ were cultured with or without DNP-KLH $(10 \mu \mathrm{g} / \mathrm{ml})$ in $2.0 \mathrm{ml}$ of
RPMI 1640 containing $10 \%$ heat-inactivated pooled human sera, 5 $\times 10^{-5} \mathrm{M} / \mathrm{ml}$ 2-mercaptoethanol, penicillin $(100 \mathrm{U} / \mathrm{ml})$, and streptomycin $(100 \mu \mathrm{g} / \mathrm{ml})$ in 96-well $U$ plate microplate (no. 9586, Costar Data Packaging Corp., Cambridge, MA). The triplicate or quadruplicate cultures were assayed individually on day 5 of the culture.

Measurement of antibody activity. Anti-DNA or anti-DNP antibody activity was measured mainly with an enzyme-linked immunosorbent assay (ELISA) (24). For ELISA of anti-DNA assay, wells were first treated with protamine $(1 \mu \mathrm{g} / \mathrm{ml})$ for $90 \mathrm{~min}$ at room temperature and then coated with DNA. The serum sample at 1:500 dilution was allowed to react with DNA or DNP-BSA coated in the wells for $90 \mathrm{~min}$ at $37^{\circ} \mathrm{C}$. After the wells were washed with PBS containing $0.05 \%$ Tween 20 and $0.2 \%$ bovine serum albumin, affinity-purified antimouse $\gamma$ goat $\mathrm{F}\left(\mathrm{ab}^{\prime}\right)_{2}$ or anti-mouse $\mu$ goat $\mathrm{F}\left(\mathrm{ab}^{\prime}\right)_{2}$ conjugated with peroxidase (Jackson Laboratories) was added. After incubation at room temperature for $90 \mathrm{~min}$, the wells were washed five times and treated in the dark for $10 \mathrm{~min}$ with $o$-phenylenediamine $(100 \mu \mathrm{l}$ per well) and absorbance was measured at $492 \mathrm{~nm}$. Quantitative immunoassay for the total IgG and IgM in each sample was also performed in microplates with ELISA. A $50-\mu \mathrm{l}$ sample was incubated at $37^{\circ} \mathrm{C}$ for 90 min with $50 \mu \mathrm{l}$ of peroxidase anti-mouse $\gamma$ goat Ig $\mathrm{F}\left(\mathrm{ab}^{\prime}\right)_{2}$ or with peroxidase anti-mouse $\mu$ goat $\operatorname{Ig} \mathrm{F}\left(\mathrm{ab}^{\prime}\right)_{2}$ in a well that had been coated with mouse IgG $(0.5 \mu \mathrm{g} / \mathrm{ml})$ or with mouse IgM $(0.5 \mu \mathrm{g} / \mathrm{ml})$. Each well was washed three times with PBS and the ELISA was then performed as described above. For each assay a 15-point standard calibration curve was prepared for IgG and IgM $(0.1-50 \mu \mathrm{g})$. Natural thymotoxic activity was also determined as follows: each sample at the appropriate dilutions was first mixed with the thymocytes from BALB/c mice and incubated at $4^{\circ} \mathrm{C}$ for $60 \mathrm{~min}$. After washing with $0.15 \mathrm{M} \mathrm{PBS}, \mathrm{pH} 7.2$, containing $1 \%$ BSA, the cells were mixed with 1:20 diluted rabbit sera (Cedarlane, CA) and again incubated for $60 \mathrm{~min}$ at room temperature. The cytotoxity was then determined by a dye exclusion test.

Measurement of anti-DNA-Id activity. Anti-DNA idiotypic activity was determined by absorption of anti-DNA-binding capacity using anti-Id antibody-conjugated affinity column. Each sample was first passed through a D1E2- or a 1F5-coupled Sepharose 4B column, and then the DNA-binding ability of the effluent was compared with those from mouse Ig-coupled Sepharose 4B columns.

Measurement of antibody-producing or Id-positive cells. Sheep red blood cells were coupled with ssDNA, dsDNA, or BSA, using $\mathrm{CrCl}_{3-}$ $6 \mathrm{H}_{2} \mathrm{O}$ as described in other papers (22). The number of plaque-forming cells (PFC) against ssDNA or dsDNA was determined by subtracting the PFC to background sheep erythrocytes from those to ssDNA or dsDNA. The specificities of PFC to DNA were checked by inhibition studies in PFC assays in which the appropriate free ssDNA, dsDNA, D1E2, or 1F5 was added to the agar slide (22).

Anti-DNA antibody-producing or anti-DNA-Id-positive cells were also determined by a modified enzyme-linked immunospot (ELISPOT) assay (31). Namely, 24-well plates (no. 3024, Falcon Labware, Oxnard, CA) were incubated with $1 \mathrm{ml}$ of ssDNA $(10 \mu \mathrm{g})$, dsDNA $(10 \mu \mathrm{g})$, or DNP-BSA $(2 \mu \mathrm{g})$ in $0.15 \mathrm{M}$ PBS, $\mathrm{pH} 7.2$, overnight at $4^{\circ} \mathrm{C}$. For DNA-coating, plates were precoated with protamine $(1$ $\mathrm{mg} / \mathrm{ml}$ ). Each well was washed and nonspecific binding sites were then blocked by incubation of $3 \%$ BSA-Tris-buffered saline for $1 \mathrm{~h}$ at $37^{\circ} \mathrm{C}$. After the plates were washed three times with Tris-buffered saline, spleen cells $\left(1 \times 10^{6}\right.$ in $1 \mathrm{ml}$ of Dulbecco's modified Eagle's medium) were plated to the well and incubated for $4 \mathrm{~h}$ in a $5 \% \mathrm{CO}_{2}$ at $37^{\circ} \mathrm{C}$. The cells were then removed from each well and biotinated anti-mouse IgG or IgM (Jackson Laboratories) were added and incubated for $1 \mathrm{~h}$ at $37^{\circ} \mathrm{C}$. Plates were again washed with Tris-buffered saline- $0.05 \%$ Tween 20 , and streptavidin alkaline phosphatase was added and incubated for $1 \mathrm{~h}$ at $37^{\circ} \mathrm{C}$. Then $0.6 \%$ agarose in the development buffer including 5-bromo, 3-chloro indylyl phosphate (Sigma Chemical Co., St. Louis, MO) was added and incubated for $1 \mathrm{~h}$, followed for $16 \mathrm{~h}$ at $4^{\circ} \mathrm{C}$. Finally, the spots were counted using an inverted microscope.

Isoelectric focusing (IEF) and immunoblotting. Flat-bed IEF was carried out in a $5 \%$ polyacrylamide gel $(10 \times 20 \times 0.1 \mathrm{~cm})$ containing 6.3\% pharmalytes, pH 3-11 (Pharmacia), 13\% glycerol, and $6 \mathrm{M}$ urea 
using a Pharmacia FBE-3000 system. The gel was prefocused at $8 \mathrm{~W}$ for $20 \mathrm{~min}$ at $4^{\circ} \mathrm{C}(21)$. Each sample, diluted to a final volume of $60 \mu \mathrm{l}$ containing $6 \mathrm{M}$ urea, was applied to the gel surface using no. 1 filter paper wicks (Whatman Inc., Clifton, NJ). The gel was then focused at $30 \mathrm{~W}$ to a maximum of $3,000 \mathrm{~V} / \mathrm{h}$ at $4^{\circ} \mathrm{C}$. The $\mathrm{pH}$ gradient was measured using a flat membrane $\mathrm{pH}$ electrode or IEF calibration kit. The focused gel was placed in a gel transfer holder, and blotted electrophoretically onto a nitrocellulose membrane in $0.7 \%$ acetic acid solution at $4^{\circ} \mathrm{C}$ for $30 \mathrm{~min}$ at $30 \mathrm{~V}$, and then for an additional $30 \mathrm{~min}$ at $150 \mathrm{~V}$. After blotting, free binding sites on the membrane were blocked by incubation in $100 \mathrm{ml}$ of $1.5 \%$ BSA in PBS containing $0.1 \%$ Tween 20 for $1 \mathrm{~h}$ at $37^{\circ} \mathrm{C}$ on a rocker platform. The membrane was rinsed three times with PBS containing 1.5\% BSA and $0.1 \%$ Tween 20 (washing buffer), overlayed with ${ }^{125} \mathrm{I}$-labeled probe (D1E2, IF5, or mouse Ig) and then incubated for $90 \mathrm{~min}$ at room temperature on the rocker. The membrane was rinsed with several changes of washing buffer with rocking for $15 \mathrm{~h}$ at room temperature, then dried and exposed to $\mathrm{X}$-ray film (X-Omat, Eastman Kodak Co., Rochester, NY) at $-70^{\circ} \mathrm{C}$.

Statistical analysis. The data were analyzed using Student's $t$ test and results with a $P$ value of $<0.05$ were considered to be statistically significant.

\section{Results}

Effect on survival. The survival rates in each group are shown in Fig. 1. Renal disease seemed the final cause of death among NZB/W $F_{1}$ mice because the mice died soon after showing massive proteinuria ( $>333 \mathrm{mg} / \mathrm{dl}$ ). In the first series of the experiments, $20 \%$ of the mice in the Ig-NCS group were alive at $11 \mathrm{mo}$ of age and $38 \%$ in the 1F5-NCS group. Only the D1E2-NCS group differed significantly in survival $\left(10^{1 / 2} \mathrm{mo} ; P\right.$ $<0.05$ ). In the second series, both control and Ig-NCS groups had died after 7 or 8 mo of age. In contrast, all mice termed anti-Id-NCS in Fig. $1 \mathrm{~B}$, which were treated with D1E2-NCS plus 1F5-NCS, were living at 9 mo of age. The prolonged survival time in this group was evident since $95 \%$ of mice were still alive at $11 \mathrm{mo}$ of age, compared with $45 \%$ in the other groups $\left(10^{1 / 2} \mathrm{mo} ; P<0.01\right)$.

Urinalysis and glomerular injuries. Serial urinalysis was used to monitor the development of renal injuries in NZB/W $F_{1}$ mice. As demonstrated in Fig. 2, half of Ig-NCS-treated or untreated mice had significant proteinuria $(>111 \mathrm{mg} / \mathrm{dl})$ at $8^{1 / 2}$ mo of age. The positive frequency of massive proteinuria in D1E2-NCS group was low compared with that in mouse IgNCS group ( 10 mo; $P<0.005$ ). Most of the Ig-NCS and untreated groups in the second series became positive for massive proteinuria ( $>333 \mathrm{mg} / \mathrm{dl}$ ), followed by death. In contrast, treatment with D1E2-NCS plus 1F5-NCS (anti-Id-NCS) prevented more significantly an early development of proteinuria ( 9 mo; $P<0.005$ ). Massive proteinuria was observed in only $14 \%$ of this group by the beginning of the 10th mo of age. However, $67 \%$ of the mice had significant proteinuria at $11 \mathrm{mo}$ of age.

The kidneys in each mice at 11 mo of age were examined microscopically for lesions, and the glomerular injury was evaluated by activity index and chronicity index. The results showed that the degree of glomerular damage was mild in the anti-Id-NCS group, when compared with that in the Ig-NCS or in the nontreated group (Table I).

Levels of anti-DNA autoantibodies in sera. Treatment of NZB/W F $F_{1}$ mice with anti-Id-NCS also prevented the development of high titers of antibodies to dsDNA as well as to ssDNA (Fig. 3). Small amounts of anti-DNA antibodies were detected at $8 \mathrm{mo}$ of age in each group. The titers of anti-DNA antibod-
(A)

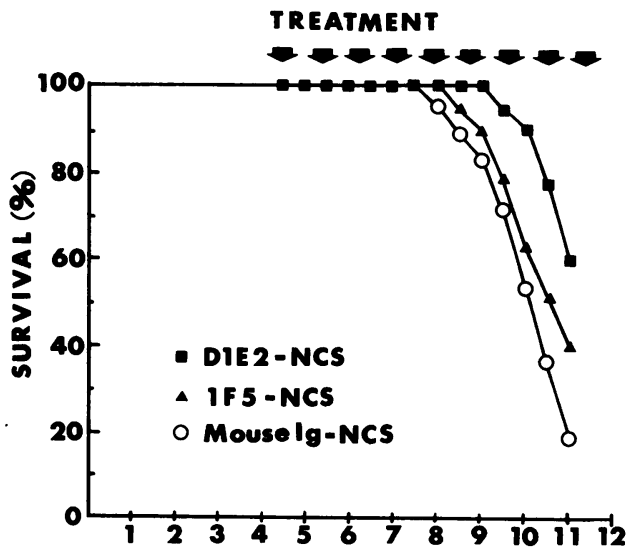

(B)

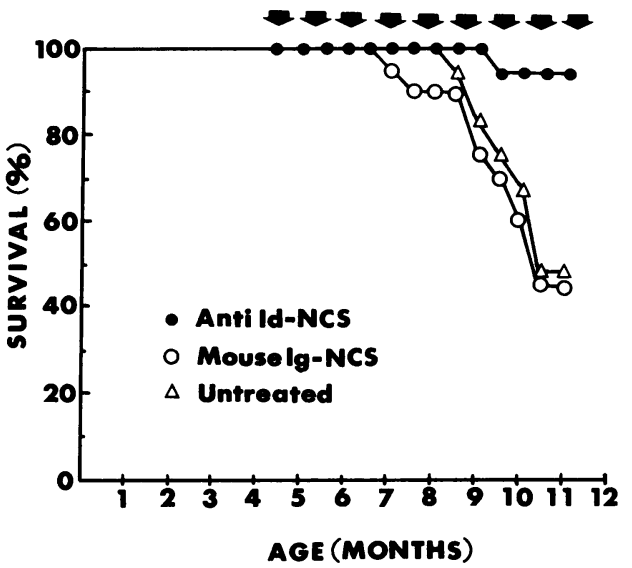

Figure 1. Comparison of survival time. $(A)$ Each group of 18 female NZB/W $F_{1}$ mice was intraperitoneally administered with D1E2NCS, 1F5-NCS, or with mouse Ig-NCS from 4 mo of age. (B) 16 and 20 mice were also given the mixture of D1E2-NCS plus 1F5-NCS, termed as anti-Id-NCS, or mouse Ig-NCS as described in Methods. 23 mice were not treated.

ies were significantly lower in anti-Id-NCS treated mice than in controls at age $11 \mathrm{mo}$. The geometric mean titers of IgGanti-dsDNA or IgG-anti-ssDNA antibody were $0.21 \pm 0.09$ or $0.20 \pm 0.08$ OD in mice treated with anti-Id-NCS, but $0.41 \pm 0.19$ or $0.29 \pm 0.17$ in mice treated with Ig-NCS, and $0.39 \pm 0.17$ or $0.31 \pm 0.13$ in untreated mice $(P<0.05$ compared with either control group; Student's $t$ test). The decrease of anti-DNA antibody production does not reflect generalized suppression of the production of antibodies to foreign antigens or other autoantibody. The levels of anti-DNP antibodies or of natural thymotoxic antibody in anti-Id-NCS treated mice were similar to those in the other groups (Table II). There was also no significant difference in the amounts of mean serum IgG among the groups.

Anti-DNA-Id activity in sera and in glomerular eluates. The quantities of anti-DNA-Id were first studied by absorption tests using anti-Id (D1E2 and 1F5)-coupled activity in sera. Fig. 3 shows that the treatment of anti-Id-NCS caused a significant decrease of Id-positive antibodies, when the absorption of anti-ssDNA antibodies was compared with those in mouse Ig-NCS and in the nontreated group $(P<0.02$ and $<0.01$ ). Id in anti-dsDNA antibodies were also low in antiId-NCS groups $(P<0.05$ and $<0.01)$. Thus, the reduction of anti-DNA antibodies in sera of anti-Id-NCS-treated mice 

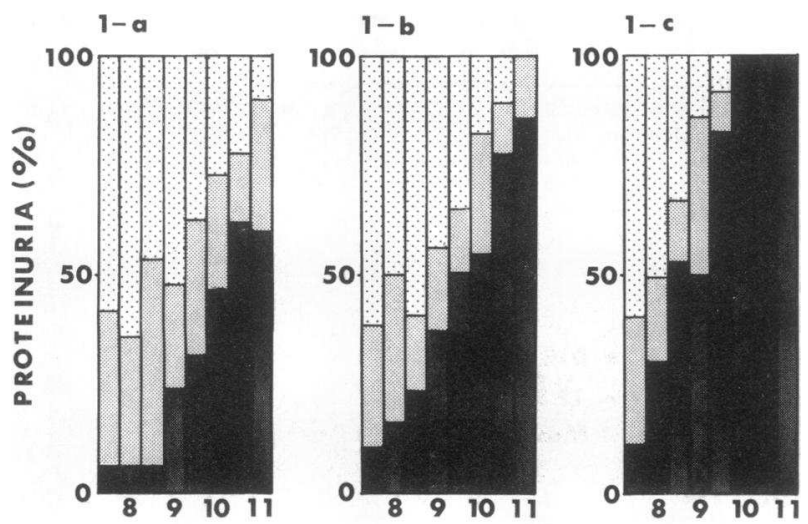

AGE (MONTHS)

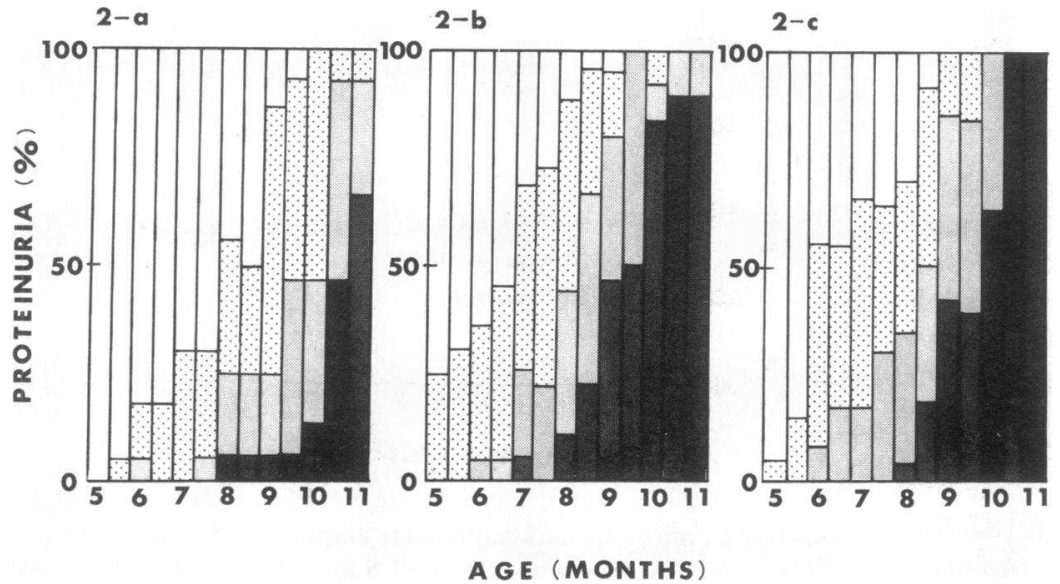

Figure 2. Frequency of proteinuria. Urinary protein in (upper panel) D1E2-NCS (1-a), 1F5-NCS (1-b), mouse Ig-NCS (1-c), and (lower panel) D1E2-NCS plus 1F5-NCS (2-a), mouse Ig-NCS (2-b), or the untreated $(2-c)$ group was determined according to the method of Knight et al. (29). Percentages reflect the current incidence of proteinuria in the surviving mice. (ㅁ) $<37 \mathrm{mg} / \mathrm{dl} ;$ (घ) $\geqq 37 \mathrm{mg} / \mathrm{dl}$; (圆) $\geqq 111$ $\mathrm{mg} / \mathrm{dl} ;$ (®) $\geqq 333 \mathrm{mg} / \mathrm{dl}$. may be mainly attributed to a decrease of anti-DNA-Id-positive antibodies, which were targeted by anti-Id antibodies. It was also noted that the amounts of anti-dsDNA antibodies with irrelevant idiotypes decreased to $51 \%$ of those in mouse Ig-NCS treated mice or to $75 \%$ in untreated mice. Similarly, those of anti-ssDNA antibodies were $65 \%$ and $87 \%$ in the controls. A decreased expression of 0-81 and NE-1 Id in serum anti-DNA antibodies was also confirmed by an IEF analysis as demonstrated in Fig. 4. The studies revealed that $56 \%$ or $64 \%$ in anti-Id-NCS-treated mice resulted in negative tests for 0-81-Id or NE-Id in sera.

Table I. Effect of Anti-Id-NCS on the Light Microscopy Histology Score

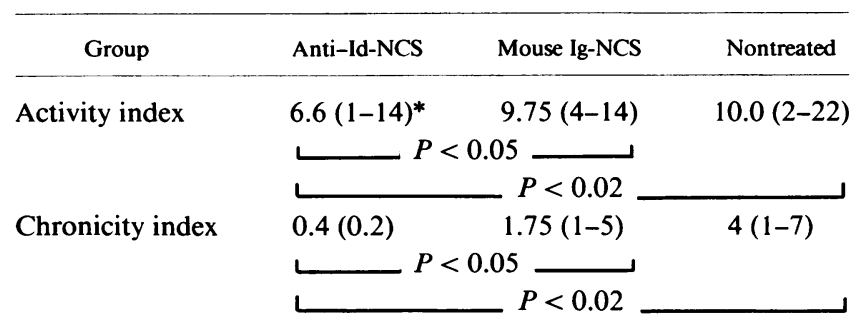

Only data of the subgroup of surviving mice of which renal histology is available are given.

* Mean (range).
The quantities of anti-DNA idiotypes in the glomerular eluates were also studied by an absorption test (Table III). 0-81 and NE-1-Id-positive anti-DNA antibodies shared with 24-42\% of total anti-DNA antibodies in the renal eluates from the untreated lupus mice. In the eluates from anti-Id-NCS group, the amounts of anti-DNA antibodies, which mainly expressed irrelevant Id, were lower than those in both control groups.

Anti-DNA PFC in spleen. The numbers of PFC specific for DNA determinants were variable when spleen cells were used in the 11 th mo. As shown in Fig. 5, all mice in control groups had above $3 \times 10^{3}$ anti-DNA PFC in the spleen, whereas some in the anti-Id-NCS group had markedly decreased PFC $(P$ $<0.01$ ). When $2 \mu \mathrm{g}$ of free anti-Id antibodies (D1E2 and 1F5) was added to spleen cells during PFC assay (blocking test), there were only half as many anti-DNA PFC as those when mouse Ig was added. However, in anti-Id-NCS group, the numbers of anti-DNA-PFC were the same whether mouse Ig or anti-Id was added (data not shown).

In vitro studies. The spleen cells were also tested for antiDNA and anti-DNP antibody-producing ability in vitro. The cultures using the spleen cells from mouse Ig-NCS or the untreated group had $21.4 \pm 1.2$ or $20.8 \pm 0.9$ dsDNA PFC and $19.7 \pm 1.8$ or $20.2 \pm 1.8$ ssDNA PFC per $1 \times 10^{6}$ spleen cells, whereas those from the anti-Id NCS group had 7.4 \pm 1.1 dsDNA PFC and $4.6 \pm 0.4$ ssDNA PFC $(P<0.02)$. The elimination of Id-positive cells in anti-Id-NCS group was clearly 


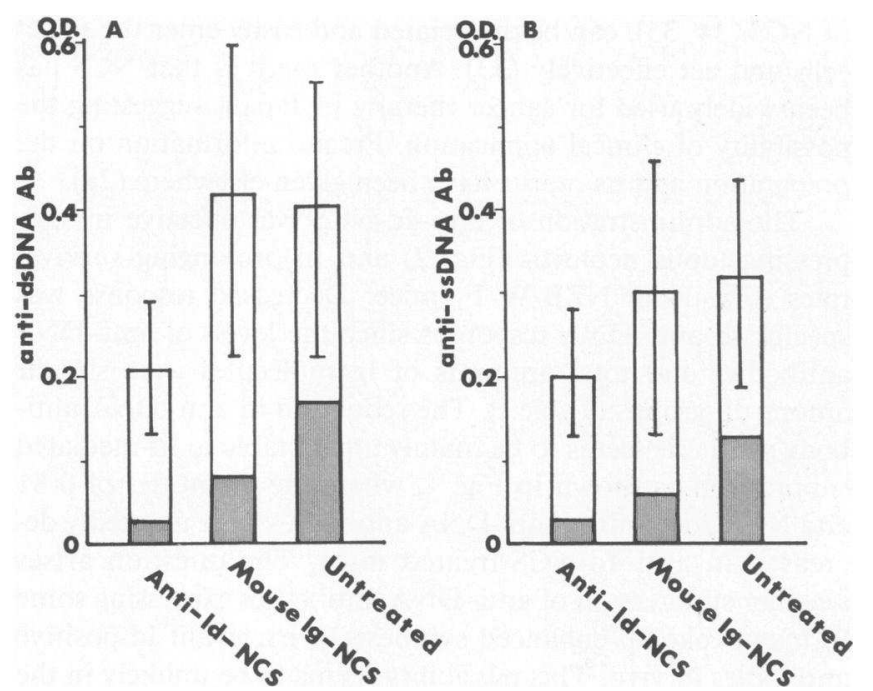

Figure 3. Anti-dsDNA and anti-ssDNA antibodies and their idiotype expression in sera at $11 \mathrm{mo}$ of age. Each serum sample at 1:500 dilution was applied to a mouse Ig-Sepharose column or to a column of the mixture including D1E2-Sepharose and 1F5-Sepharose. $(A)$ Anti-dsDNA antibody and $(B)$ anti-ssDNA antibody activity in each sample was determined before or after passing through the column by ELISA as described in Methods (mean OD $\pm S E$ ). The numbers of mice in each group: D1E2-NCS plus 1F5-NCS, termed anti-Id-NCS $(n=14)$, mouse Ig-NCS $(n=5)$, the untreated $(n=10)$. (田) Idiotypepositive portions of the total IgG anti-DNA antibodies expressed as DNA-binding of the effluent from mouse Ig Sepharose column minus that from anti-Id (D1E2 plus 1F5)-coupled Sepharose column. (ㅁ) Idiotype-negative portions of the total IgG anti-DNA antibodies.

shown when D1E2- or 1F5-binding cells were directly counted by an ELISPOT assay (Table IV). Anti-DNP responses after the stimulation of DNP-KLH in vitro were similar among the untreated, Ig-NCS, and anti-Id-NCS groups.

\section{Discussion}

In the present study, we demonstrated a successful manipulation of the production of spontaneously occurring anti-DNA antibodies in autoimmune NZB/W $F_{1}$ mice through anti-Id immunity. Anti-Id antibodies used were originally developed against Id of human monoclonal anti-DNA antibodies. D1E2 recognized Id in antigen binding sites of anti-ssDNA antibodies, 0-81. 1F5 specifically reacts with Id in paratopes of antidsDNA antibodies, NE-1. Both Id were commonly expressed on anti-DNA autoantibodies or surface immunoglobulins of
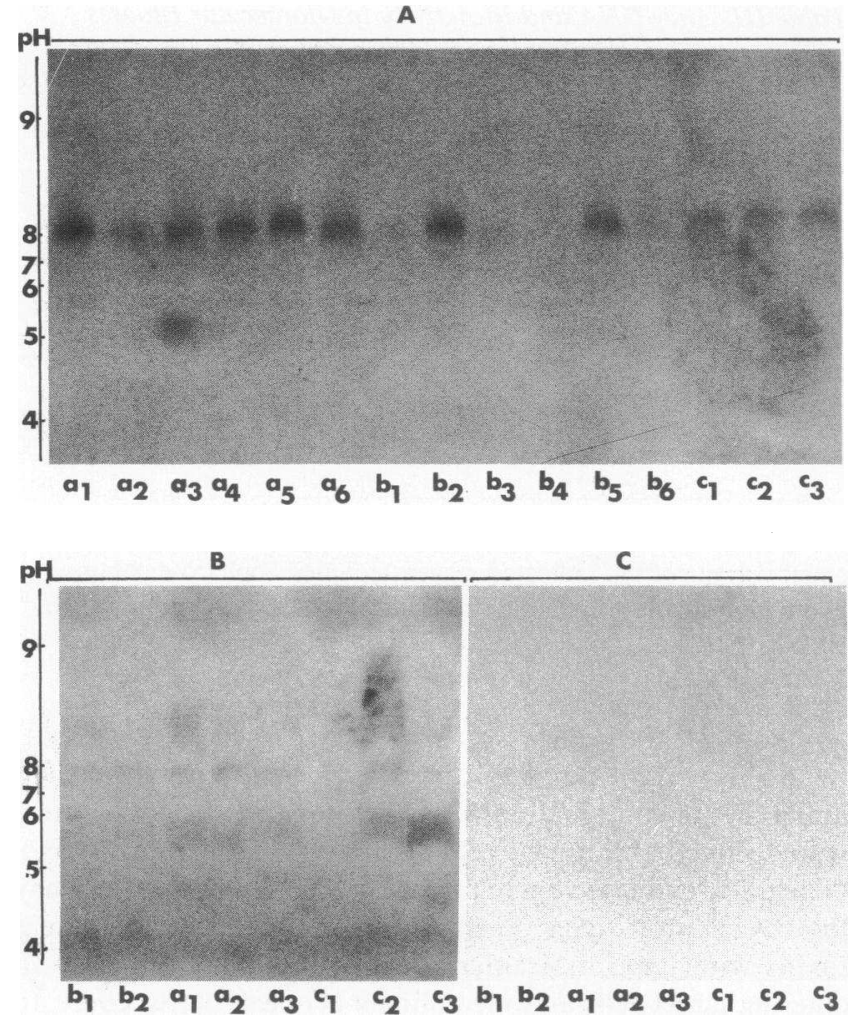

Figure 4. Idiotype expression in sera. The sera were obtained from (a) Ig-NCS-treated mice, $(b)$ anti-Id-NCS-treated, and $(c)$ the untreated at 11 mo of age. Spectrotypic patterns were then analyzed by IEF using ${ }^{125}$ I-labeled $(A) 1 \mathrm{~F} 5,(B) \mathrm{D} 1 \mathrm{E} 2$, or $(C)$ mouse anti- $\gamma$ as probes.

B cells from patients with SLE, especially with active lupus nephritis (21). We have also observed that 0-81 and NE-1 Id were associated with renal lesions of SLE, based on the deposition in renal glomeruli of active lupus patients and the specific detection of circulating immune complexes involving 0-81 Id in patients with renal lesions (20). Thus, 0-81 and NE-1 Id are markers of nephritogenic antibodies in human SLE, and antiDNA antibodies expressing these Id may play an important role in the pathogenesis of lupus nephritis. We then proved that 0-81 and NE-1 Id were interspecies Id, distributed in murine anti-DNA antibodies as well as in humans (32). These Id were also expressed on anti-DNA autoantibodies in NZB/W $F_{1}$ mice as shown in Fig. 5. Based on the above mentioned data, we tried to achieve selective suppression of anti-DNA antibody production in NZB/W $F_{1}$ mice by using D1E2 and 1F5.

Table II. Level of Serum Antibodies in Mice at 11 mo of Age

\begin{tabular}{lccrr}
\hline \multicolumn{1}{c}{ Group } & No. of mice & IgG anti-DNP Ab* & IgM anti-DNP Ab* & Notal IgG $^{*}$ \\
\hline Anti-Id-NCS & 9 & $0.343 \pm 0.079$ & $0.281 \pm 0.079$ & $5.43 \pm 0.30$ \\
Mouse Ig-NCS & 5 & $0.362 \pm 0.165$ & $0.282 \pm 0.139$ & $4.94 \pm 0.22$ \\
$(-)$ & 9 & $0.357 \pm 0.114$ & $0.273 \pm 0.087$ & $5.84 \pm 1.03$
\end{tabular}

* Spontaneously occurring anti-DNP antibody activity in 1:100 diluted serum was measured by ELISA as described in Methods. Anti-DNP activity was expressed as total binding to DNP-BSA minus that to BSA (mean OD $\pm \mathrm{SE})$. ${ }^{\ddagger} \mathrm{Mean} \pm \mathrm{SE}(\mathrm{mg} / \mathrm{ml})$. ${ }^{\S}$ Natural thymocytoxic antibody titers were expressed as the maximum dilutions $(\log 2)$ of serum for cytoxic activity to BALB/c thymocytes. 
Table III. Anti-DNA and Id Activity in Glomerular Eluates

\begin{tabular}{clcc}
\hline \multicolumn{1}{c}{ Group } & Preabsorption & Anti-ssDNA Ab & Anti-dsDNA Ab \\
\hline Anti-Id-NCS & Mouse Ig & $0.236^{*}$ & $0.284^{*}$ \\
& D1E2 + 1F5 & 0.211 & 0.274 \\
Mouse Ig-NCS & DNA & 0.051 & 0.037 \\
& Mouse Ig & 0.542 & 0.431 \\
& D1E2 + 1F5 & 0.317 & 0.303 \\
Nontreated & DNA & 0.075 & 0.060 \\
& Mouse Ig & 0.508 & 0.423 \\
& D1E2 + 1F5 & 0.403 & 0.289 \\
& DNA & 0.048 & 0.072
\end{tabular}

The glomerular eluates at 1:50 dilution were first passed through an equal volume of the indicated reagent-coupled Sepharose column, and then tested for direct binding ability to ssDNA or to dsDNA by ELISA.

* Value in $\mathrm{OD}_{492}$.

An important point in our strategy is the use of anti-Id antibodies in combination with a cytotoxic agent, NCS, which would directly eliminate relevant Id-positive clones in vivo. Generally, cytotoxic agents with low molecular weights may lose their cytotoxicity during the coupling process, whereas toxins with large molecular weights may have difficulty in entering target cells and mediating a cytodestructive effect. In addition, even after binding to the corresponding cells, anti-Id antibodies covalently conjugated with cytotoxic agents seem unsuited to deliver toxins into the cytoplasma because the antibody complexes can be endocytosed only with difficulty. The reason for our choice of NCS is that it has theoretical and practical advantages over other immunotoxins or cytotoxic agents for eliminating the target clones. The apoprotein that is not the active part of NCS, is responsible for binding to anti-Id antibodies through its reaction with the coupling agent SPDP (33). Therefore, the chromophore, another component of NCS, can retain its pharmacological activity in an intact form after the coupling procedure (28). After binding to Id determinants on the cell surface, the chromophore, or the active part of NCS $(34,35)$, can be dissociated and easily enter the target cells and act effectively (33). Another merit is that NCS has been widely used for cancer therapy in Japan, suggesting the possibility of clinical application. Precise information on the preparation and its merits have been given elsewhere (28).

The administration of anti-Id-NCS was effective in suppressing lupus nephritis (Fig. 2) and in prolonging survival rates (Fig. 1) in NZB/W $F_{1}$ mice. Decreased response was specific to anti-DNA responses since the levels of anti-DNP antibodies and total amounts of $\mathrm{Ig}$ molecules were similar among all groups (Table I). The reduction in anti-DNA antibody synthesis seems to be mainly attributable to Id-mediated suppression as shown in Fig. 4, where the quantities of 0-81 and NE-1 Id-positive anti-DNA antibodies were markedly decreased in anti-Id-NCS-treated mice. The question arises whether suppression of anti-DNA antibodies expressing some Id may evoke an enhanced synthesis of irrelevant Id-positive antibodies in vivo. This possibility seems to be unlikely in the present system because the amounts of 0-81 and NE-1-Id-negative anti-DNA antibodies were decreased, compared to those in control mice (Fig. 4). The targets by anti-Id-NCS treatment may be B cells because the numbers of anti-DNA PFC in the spleen were decreased in half in the anti-Id-treated mice at 11 months of age. The cells from this group also had a diminished ability to produce anti-DNA PFC in vitro. D1E2-NCS directly killed 0-81 Id-positive B cells in human in vitro system (19, 21 ). Thus, the reduction may be mainly due to the elimination of Id-positive antibody-producing cells. The suppression, however, could not be explained solely by the elimination of Idpositive $B$ cells, since Id-negative anti-DNA antibodies were also decreased in the treated mice. This is interesting from the view point of Id-related $T$ cell regulation. Anti-Id antibodies are capable of evoking an activation of $\mathrm{T}$ cells with helper or with suppressor activity (36). Anti-Id-NCS would eliminate T cells directly responsive to anti-Id antibodies through the cytotoxic action of NCS. Recent works have also demonstrated that Id-specific $\mathrm{T}$ cells could be generated through interacting with Id-positive B cells and then modify specific immune responses. The induced $\mathrm{T}$ cells may have the ability to work to a wide range of $B$ cell repertoires. The procedure in this paper
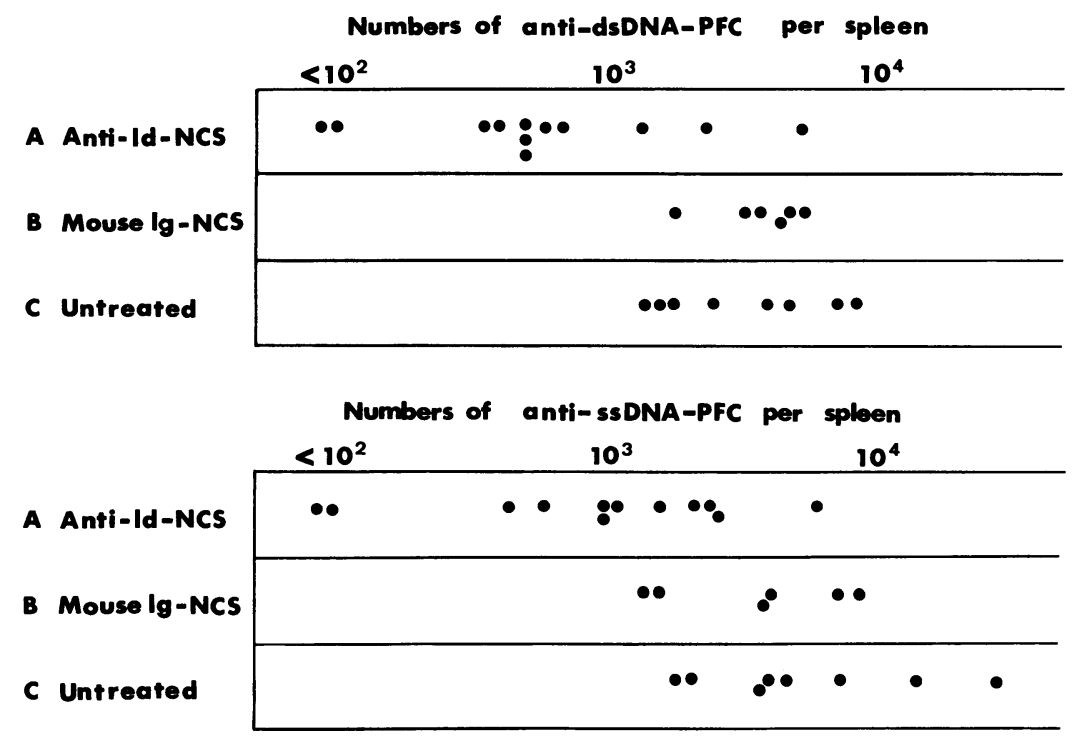

Figure 5. Anti-DNA PFC in spleen. 


\begin{tabular}{lccccc}
\hline & \multicolumn{5}{c}{ No. of antibody-producing cells } \\
\cline { 2 - 6 } \multicolumn{1}{c}{ Group } & ssDNA & dsDNA & D1E2 & 1F5 & DNP* \\
\hline Anti-Id-NCS $(n=5)$ & $4.6 \pm 0.14^{\ddagger}$ & $7.4 \pm 1.1^{\ddagger}$ & $0.1 \pm 0.1^{\S}$ & 0 & $149.2 \pm 7.1^{\ddagger}$ \\
Mouse Ig-NCS $(n=5)$ & $19.7 \pm 1.8$ & $21.4 \pm 1.1$ & $4.8 \pm 0.6$ & $4.6 \pm 0.5$ & $146.1 \pm 4.9$ \\
Untreated $(n=5)$ & $20.2 \pm 1.8$ & $20.8 \pm 0.9$ & ND & ND & $143.0 \pm 2.9$ \\
\hline
\end{tabular}

Spleen cells $\left(1 \times 10^{6}\right)$ were incubated without any antigens for $5 \mathrm{~d}$ in $5 \% \mathrm{CO}_{2}$ at $37^{\circ} \mathrm{C}$ and then tested for ELISPOT assay as described in Methods. ND, not determined. * Spleen cells $\left(1 \times 10^{6}\right)$ from each group were stimulated with DNP-KLH $(10 \mu \mathrm{g} / \mathrm{ml})$ in vitro, cultured in $5 \%$ $\mathrm{CO}_{2}$ at $37^{\circ} \mathrm{C}$, and washed $48 \mathrm{~h}$ later. Then the cells were again cultured in $5 \% \mathrm{CO}_{2}$ at $37^{\circ} \mathrm{C}$ for $5 \mathrm{~d}$ and tested for ELISPOT assay. ${ }^{\ddagger}$ Average number of IgG-type antibody-producing cells per $10^{6}$ spleen cells $\pm \mathrm{SE}$. ${ }^{8}$ Average number of IgM-type antibody-producing cells per $10^{6}$ spleen cells $\pm \mathrm{SE}$.

will inhibit the expansion of Id-specific $\mathrm{T}$ cells by blocking their interaction with Id-positive B cells, which are eliminated by anti-Id-NCS (21). This may result in a diminished antiDNA synthesis in vivo. This mechanism is theoretically different from that related to the administration of anti-Id antibody alone, and may be partly responsible for decreased antiDNA antibody synthesis in vivo with anti-Id-NCS treatment.

A problem still remains concerning the application of anti-Id immunity for the therapy of autoimmune diseases. Anti-Id antibodies have the ability to strictly discriminate Idpositive clones from many irrelevant cells. Autoantibodies, however, are heterogenous and, therefore it may be asked whether anti-Id antibodies are capable of bringing about a sufficient suppression of in vivo autoantibody synthesis. There are at least two ways of overcoming this problem. One is to obtain anti-Id antibodies with $\mathrm{Ab} 2 \alpha$ or $\mathrm{Ab} 2 \gamma$ activity, which are able to react with Id common among a wide range of autoantibodies. Another is the use of anti-Id antibodies recognizing pathogenic autoantibodies. This is based on the hypothesis that a selective manipulation of pathogenic antibodies may result in blocking of development of tissue injuries through the autoimmune process. We recently obtained data that the numbers of nephritogenic anti-DNA antibodies are restricted in human SLE although serum anti-DNA antibodies are markedly heterogenous (20). This indicates the possibility of controlling pathogenic antibody synthesis by a limited number of anti-Id antibodies. In fact, the above-mentioned idea is supported by the present paper, which showed that the mixture of two monoclonal anti-Id antibodies conjugated with NCS has the ability to bring about an improvement in the survival rate of NZB/W $F_{1}$ mice. We failed to completely inhibit the development of lupus nephritis in NZB/W $F_{1}$ mice. Previous studies have demonstrated that the viral envelope glycoprotein (gp) 70-associated immune complexes are the other major factors responsible for the renal injuries in $\mathrm{NZB} / \mathrm{W} \mathrm{F}_{1}$ mice (36). Anti-Id antibodies used in this experiments may not be reactive to anti-gp 70 antibodies so that the administration of anti-Id-NCS might be unable to suppress the production of $\mathrm{gp} 70$-associated immune complexes. Thus, gp 70 immune complexes might be at least partly responsible for the development of immune complexes nephritis in antiId-NCS groups.

Taken together, the presented data suggest the feasibility of employing anti-Id immunity for the therapy of autoimmune diseases. Further studies to obtain human monoclonal anti-Id antibodies are in progress.

\section{Acknowledgments}

We thank Miss M. Suzuki for preparing the manuscript.

This work was supported by a grant-in-aid for scientific research from the Ministry of Education, Science and Culture, and by a research grant for autoimmune diseases from the Ministry of Health and Welfare, Japan.

\section{References}

1. Dwyer, D. S., R. J. Bradley, C. K. Urguart, and J. F. Kearney. 1983. Naturally occurring anti-idiotypic antibodies in myasthenia gravis patients. Nature (Lond.). 301:611-614.

2. Rose, W. F. 1971. Quantitative immunology of immune hemolytic anemia. II. The relationship of cell bound antibody to hemolysis and the effect of treatment. J. Clin. Invest. 50:734-743.

3. Abdou, N. I., H. Wall, H. B. Lindsley, J. F. Halsey, and T. Suzuki. 1981. Network theory in autoimmunity. In vitro suppression of serum anti-DNA antibody binding to DNA by anti-idiotypic antibody in systemic lupus erythematosus. J. Clin. Invest. 67:1297-1304.

4. Koopman, W. J., R. E. Schrohenloher, J. C. Barton, and E. C. Greenliaf. 1983. Suppression of in vitro monoclonal human rheumatoid factor synthesis by anti-idiotypic antibody. J. Clin. Invest. 72:1410-1419.

5. Zanetti, M. 1985. The idiotype network in autoimmune processes. Immunol. Today. 6:299-302.

6. Eichman, K., and K. Rajewsky. 1975. Induction of T and B cell immunity by anti-idiotypic antibody. Eur. J. Immunol. 5:661-666.

7. Bona, C., and W. E. Paul. 1979. Cellular basis of regulation of expression of idiotype. I. T-suppressor cells specific for MOPC 460 idiotype regulate the expression of cells secreting anti-TNP antibodies bearing 460 idiotype. J. Exp. Med. 149:592-600.

8. Bona, C., C. Victor-Kobrin, and A. J. Manheimer. 1984. Regulatory arms of the immune network. Immunol. Rev. 79:25-40.

9. Agius, M. A., and D. P. Richman. 1986. Suppression of development of experimental autoimmune myasthenia gravis with isogeneic monoclonal anti-idiotypic antibody. J. Immunol. 137:2195-2198.

10. Epstein, A., M. Greenberg, B. Diamond, and A. I. Greyzel. 1987. Suppression of anti-DNA antibody synthesis in vitro by a crossreactive anti-idiotypic antibody. J. Clin. Invest. 79:997-1000.

11. Takeuchi, O., O. Hosono, J. Koide, M. Homma, and T. Abe. 1985. Suppression of rheumatoid factor synthesis by anti-idiotypic antibody in rheumatoid arthritis patients with cross-reactive idiotypes. Arthritis. Rheum. 28:873-881.

12. Deshambo, R. M., and K. A. Krolick. 1986. Selective in vitro inhibition of an antibody response to purified acetylcholine receptor by using anti-idiotypic antibodies coupled to the A chain of ricin. $J$. Immunol. 137:3135-3139.

13. Takemori, T., and K. Rajewsky. 1984. Specificity, duration and mechanism of idiotype suppression induced by neonatal injection of 
monoclonal anti-idiotype antibodies into mice. Eur. J. Immunol. 14:656-667.

14. Sim, G. K., and A. A. Augustin. 1983. Internal images of major histocompatibility complex antigens on T-cell receptors and their role in the generation of the T-helper cell repertoire. Ann. NY Acad. Sci. 418:272-281.

15. Zanetti, M., J. Rogers, and D. H. Katz. 1984. Induction of autoantibodies to thyroglobulin by anti-idiotypic antibodies. $\mathrm{J}$. Immunol. 133:240-243.

16. Hahn, B. H., and F. M. Ebling. 1984. Suppression of murine lupus nephritis by administration of anti-idiotypic antibody to antiDNA. J. Immunol. 123:187-190.

17. Teitelbaum, D., J. Rauch, B. D. Stollar, and R. S. Schwartz. 1984. In vivo effects of antibodies against a high frequency idiotype of anti-DNA antibodies in MRL mice. J. Immunol. 123:1282-1285.

18. Yamamoto, H., and D. H. Katz. 1980. Biological effects of anti-idiotypic antibodies on lymphocyte function. I. Analysis of the effects on B lymphocytes of combining site and framework-directed anti-T-15 idiotypic antibodies. Cell. Immunol. 50:369-378.

19. Sasaki, T., T. Muryoi, O. Takai, E. Tamate, Y. Ono, Y. Koide, N. Ishida, and K. Yoshinaga. 1986. Selective elimination of anti-DNA antibody-producing cells by anti-idiotypic antibodies conjugated with neocarzinostatin. J. Clin. Invest. 77:1382-1384.

20. Muryoi, T., T. Sasaki, A. Hatakeyama, S. Shibata, T. Seino, and K. Yoshinaga. 1989. The clonotypes of anti-DNA antibodies expressing specific idiotypes in circulating immune complexes of patients with active lupus nephritis. J. Immunol. In press.

21. Sasaki, T., E. Tamate, T. Muryoi, O. Takai, and K. Yoshinaga. 1989. In vitro manipulation of human anti-DNA antibody production by anti-idiotypic antibodies conjugated with neocarzinostatin. J. Immunol. 142:1159-1165.

22. Sasaki, T. 1981. Passive hemagglutination and hemolysis test for anti-DNA antibody. Methods Enzymol. 84:291-295.

23. Sasaki, T., F. Endo, Y. Sekiguchi, M. Mikami, K. Tada, N. Ishida, and K. Yoshinaga. 1984. Establishment of human monoclonal anti-DNA producing cell lines. J. Immunol. Methods. 72:157-165.

24. Sasaki, T., T. Muryoi, Y. Sekiguchi, E. Tamate, K. Yoshinaga, and Y. Kitagawa. 1985. Monoclonal human anti-DNA antibodies from EB virus-transformed lymphocytes of SLE patients. J. Clin. Immunol. 5:246-253.

25. Tamate, E., T. Sasaki, T. Muryoi, O. Takai, K. Otani, K. Tada, and K. Yoshinaga. 1986. Expression of idiotype on the surface of human B cells producing anti-DNA antibody. J. Immunol. 136:1241-1246.

26. Muryoi, T., T. Sasaki, E. Tamate, O. Takai, N. Harata, and K. Yoshinaga. 1987. Antigen inhibition of the interaction between murine monoclonal anti-idiotypic antibodies and human anti-DNA antibodies. Tohoku J. Exp. Med. 50:264-267.

27. Kavanach, F. 1975. Antibiotic assays-principles and precautions. Methods Enzymol. 43:55-69.

28. Sasaki, T., Y. Koide, and K. Yoshinaga. 1989. Immune suppression of anti-DNA antibody production using anti-idiotypic antibody-neocarzinostatin conjugates. Methods Enzymol. 178:422-432.

29. Knight, J. G., O. D. Adams, and H. D. Purves. 1977. The genetic contribution of the NZB mouse to the renal disease of the NZB $\times$ NZW hybrid. Clin. Exp. Immunol. 28:352-358.

30. Austin, H. A. III, L. R. Muenz, K. M. Joyce, T. T. Antonovych, and J. E. Balow. 1984. Diffuse proliferative lupus nephritis: Identification of specific pathologic features affecting renal outcome. Kidney Int. 25:689-695.

31. Ando, D., F. M. Ebling, and B. H. Hahu. 1986. Detection of native and denatured DNA antibody forming cells by the enzymelinked immunospot assay. Arthritis Rheum. 29:1139-1146.

32. Sasaki, T., S. Shibata, N. Harata, E. Tamate, and K. Yoshinaga. 1989. Idiotype network and anti-DNA antibody production. In Molecular and Cell Biology of Autoantibodies and Autoimmunity. E. K. F. Bautz, J. R. Kalden, M. Homma, and E. M. Tan, editors. Springer-Verlag, Berlin. 79-80.

33. Jung, G., W. Köhnlein, and G. Löders. 1981. Biological activity of the antitumor protein neocarzinostatin coupled to a monoclonal antibody by $\mathrm{N}$-succinimidyl 3-(2-pyridylthio)-propionate. Biochem. Biophys. Res. Commun. 101:599-606.

34. Edo, K., M. Mizugaki, Y. Koide, H. Seto, K. Furihata, N. Otake, and N. Ishida. 1985. The structure of neocarzinostatin chromophore possessing a novel bicyclo $[7,3,0]$ dedecadiyne system. Tetrahedron Lett. 26:331-334.

35. Goldenberg, I. H. 1986. Novel types of DNA-sugar damage in neocarzinostatin cytotoxicity and mutagenesis. In Mechanism of DNA Damage and Repair. M. G. Simic, L. Grossmann, and A. C. Upton, editors. Plenum Press, New York. 231-243.

36. Yoshiki, T., R. C. Mellors, M. Strand, and J. T. August. 1974. The viral envelope glycoprotein of murine leukemia virus and the pathogenesis of immune complex glomerulonephritis of New Zealand mice. J. Exp. Med. 140:1011-1027. 